\title{
Plasma Surface Modification of POSS-PCU with Allylamine Enhances the Response and Osteogenic Differentiation of Adipose-Derived Stem Cells
}

\author{
Camilo Chaves $^{1,2}$, Feras Alshomer ${ }^{1}$, Robert G.Palgrave ${ }^{3}$, Deepak Kalaskar ${ }^{1} *$
}

${ }^{1}$ UCL Centre for Nanotechnology and Regenerative Medicine, Division of Surgery \& Interventional

Science, University College London, London, United Kingdom, NW3 2PF.

${ }^{2}$ Université Paris Sud, Orthopedic Surgery, Hôpital Saint Antoine, 184, rue du Faubourg-Saint-Antoine, Paris, France, 75012.

${ }^{3}$ Department of Chemistry, University College London, 20 Gordon Street, London, United Kingdom, WC1H

OAJ.

*Corresponding author:

Dr Deepak M Kalaskar

Lecturer in Nanotechnology and Cellular Engineering

Centre for Nanotechnology and Regenerative Medicine

Division of Surgery \& Interventional Science

Rowland Street, NW3 2PF

University College London,

London, United Kingdom.

E-mail: d.kalaskar@ucl.ac.uk 


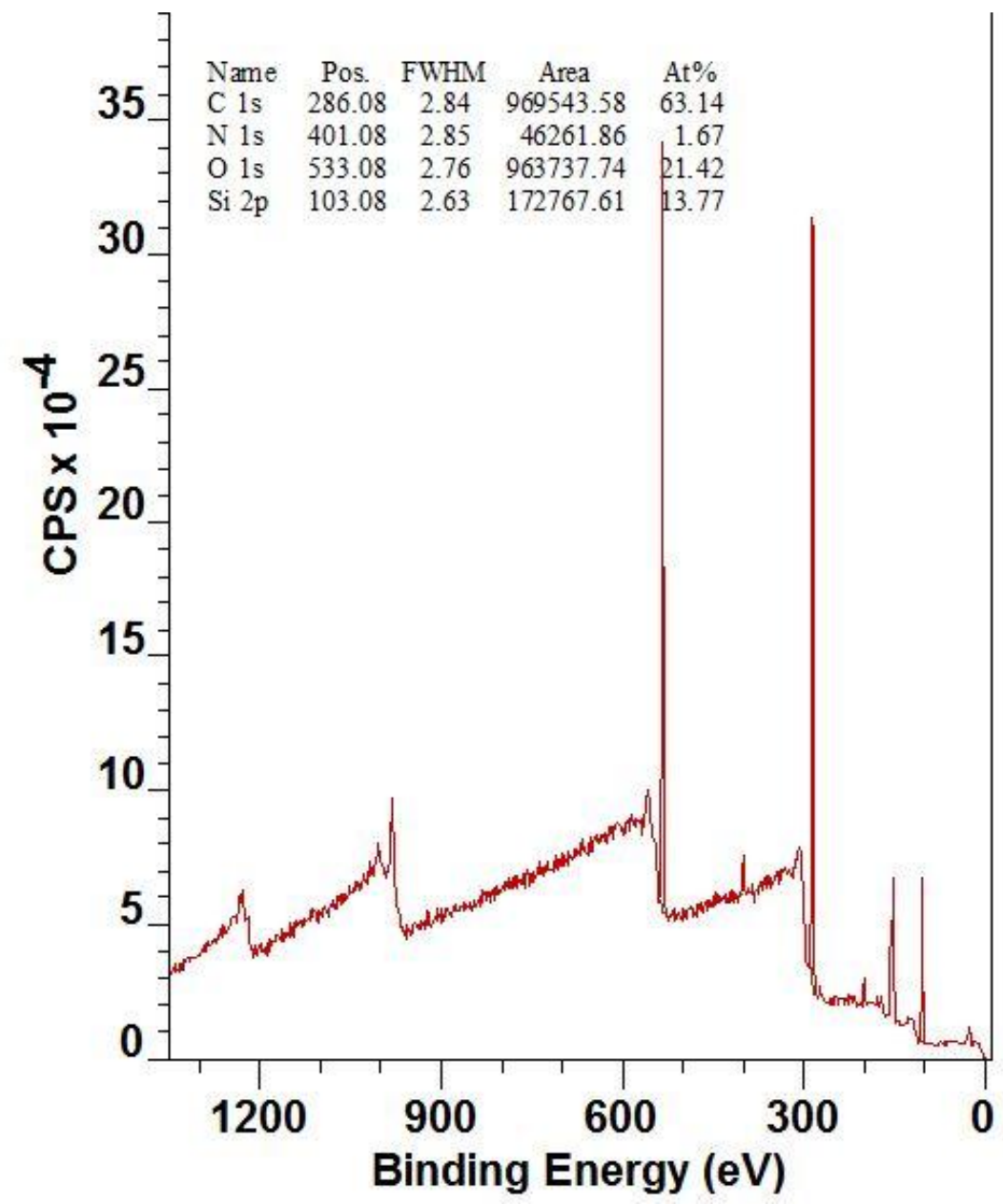

Figure S1. XPS Survey spectrum of elemental composition of POSS-PCU. 
Supporting Information

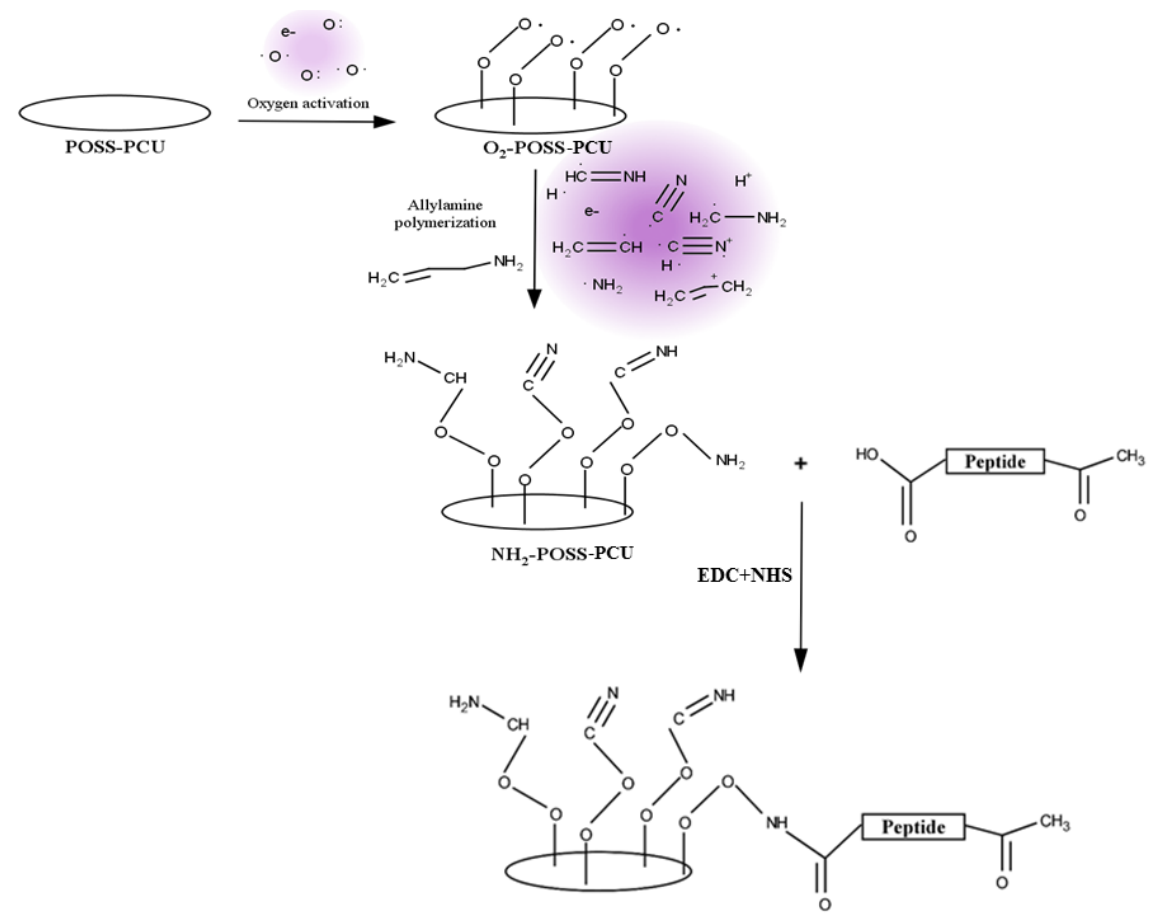

Figure S2. Schematic diagram of plasma polymerization using allylamine followed by peptide coupling on POSS-PCU polymer using conventional EDC-NHS chemistry. 